\title{
Implications of extremely high recruitment: crowding and reduced growth within spatial closures
}

\author{
N. David Bethoney*, Kevin D. E. Stokesbury \\ School for Marine Science and Technology, University of Massachusetts Dartmouth, New Bedford, \\ Massachusetts 02744-1221, USA
}

\begin{abstract}
The influence of density on population dynamics is a fundamental concept of ecology; however, observations of marine populations affected by density are rare. Recently, extremely high abundances of Atlantic sea scallops Placopecten magellanicus have persisted over a wide range of their distribution, including 2 adjacent areas on Browns Bank, Canada, that were closed to fishing from 2014 to 2016. We hypothesized that the closures, named C2 and C3, would work as expected, i.e. scallop abundance would decrease through time due to natural mortality, while yield would substantially increase due to growth. To test this, we compared the density (number of scallops per unit area), crowding levels (number of scallops around an individual scallop), and shell growth of scallops through the closures. Despite similar scallop densities in each area, crowding levels were significantly higher within area C2 than in C3. This contrasting result suggests the intensity of scallop aggregation was significantly higher in area C2. This area also had individuals with reduced shell height growth in the final year of the closure. Combined, the results show yield was lost between Years 2 and 3 in area C2 while yield increased through time in area $\mathrm{C} 3$. The different levels of crowding between the 2 areas may explain the different growth patterns; factors causing discrepancies in scallop growth can be related to aggregation intensity. Spatial closures to increase fishery yield are commonly thought of as 'money in the bank', but divergences from typical patterns, in this case growth, suggest considering these areas as shorter term 'windows of opportunity' will help their management.
\end{abstract}

KEY WORDS: Density dependence $\cdot$ Marine protected areas $\cdot$ Atlantic sea scallop

\section{INTRODUCTION}

The implementation of marine protected areas has increased substantially over the last century and will likely continue to increase to meet global conservation targets (Boonzaier \& Pauly 2016). Since the biomass and density of animals within marine protected areas generally increase, marine protected areas have been used as fishery management tools to increase harvest and reduce impact on the sea floor and on non-target species (Murawski et al. 2000, Guidetti \& Claudet 2010, McDermott et al. 2017). If this management strategy is increasingly employed, accounting for density-dependent changes in growth and mortality will be important (Beverton \& Holt

*Corresponding author: nbethoney@umassd.edu
1957). Though the impact of density on fish population dynamics is a fundamental concept, it is difficult to monitor wild marine populations at extremely high levels to observe this effect (Rose et al. 2001). Fortunately, the status of the Atlantic sea scallop Placopecten magellanicus population presents an opportunity to study this phenomenon.

The Atlantic sea scallop fisheries in the USA and Canada have dramatically increased in value since the 1990s, with scallop landing values approximately tripling in the US (NOAA 2016) and doubling in Canada (DFO 2015). Though economic factors have increased the price of scallops, increases in landings are linked to surges in scallop abundance and density (Stokesbury et al. 2016, NEFSC 2018). Recent

(C) The authors 2019. Open Access under Creative Commons by Attribution Licence. Use, distribution and reproduction are unrestricted. Authors and original publication must be credited. 
extreme recruitment events have resulted in high densities of scallops over an unpreceded spatial scale, which has greatly impacted the overall abundance of scallops (Bethoney et al. 2016, DFO 2017). A key tool in both the US and Canadian fisheries are spatial closures of 2 to $5 \mathrm{yr}$ to protect high scallop recruitment events (Stevens et al. 2008, Orensanz et al. 2016). The objective is to take advantage of the exponential growth scallops undergo when they are young (Thouzeau et al. 1991, Hart \& Chute 2009, MacDonald et al. 2016), as gains in meat weight during this time far exceed decreases in abundance, creating a more efficient and less impactful fishery (NEFMC 2004). However, the gains from exponential growth and the effectiveness of temporary closures are reduced if population dynamics change due to density-dependent processes (Beverton \& Holt 1957).

Here, we examined 2 adjacent areas on Browns Bank, Canada, with extremely high densities of scallops over a 3 yr closure (Fig. 1). The density, crowding levels, and shell height distributions of scallops within each area were estimated annually using a drop camera survey and compared within and between the 2 areas. Scallop crowding differs from density as it reflects the number of scallops around an individual scallop, not the number of scallops per unit area (Lloyd 1967). This difference allows crowding to potentially identify small-scale distribution patterns and concentrations - which have implications for the density-dependent process - in areas that have the same density (Orensanz et al. 2016). For example, 2 locations sampled with 4 quadrats would have the same density if one location had 4 quadrats with 5 scallops and the other location had 3 quadrats with zero scallops and one quadrat with 20 scallops. In contrast, crowding would be much higher in the location with 20 scallops in one quadrat, reflecting the more intense aggregation of scallops. In areas closed to protect a large scallop recruitment, scallop densities are expected to decrease over time due to natural mortality, while biomass should increase due to growth (Orensanz et al. 2016). We hypothesized that the closures would work as expected, with density and crowding levels decreasing and shell height increasing through time. The 2 closed areas were approximately $7 \mathrm{~km}$ apart and assumed to have the same growth parameters (Hubley et al. 2014). Therefore, we hypothesized there would be no significant different in density, crowding levels, and shell height between the 2 areas. However, we found that there were significant differences between the 2 areas: one area had higher levels of crowding and reduced shell height growth compared to the other. We discuss how substrate composition may have influenced these differences and the implications these findings have on spatial closures as management tools.

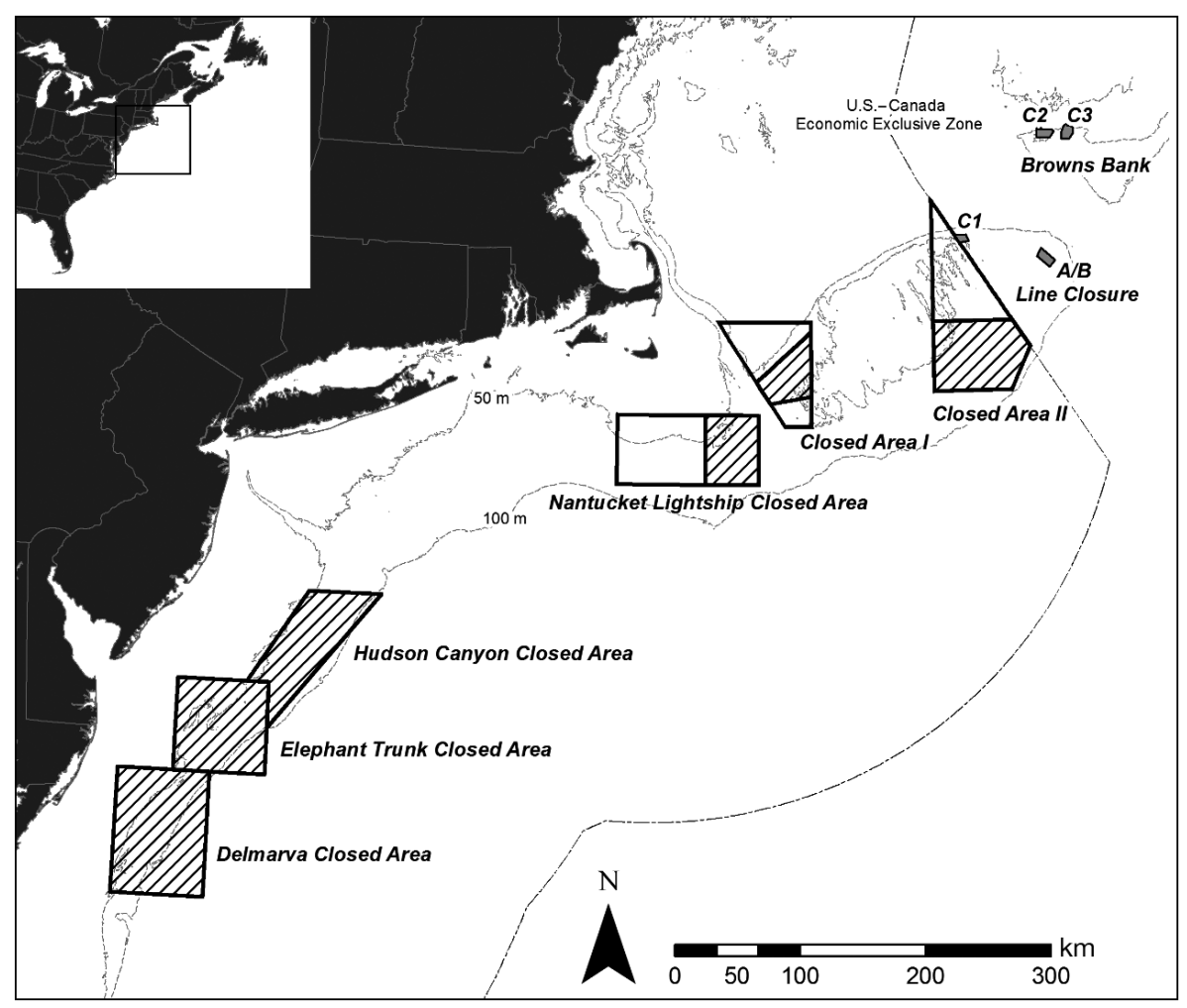

Fig. 1. Marine protected areas related to Atlantic sea scallop fishing on the northeastern US and southeastern Canadian continental shelf in 2014. Black outlined areas: long-term habitat and groundfish protection areas; hashed areas: periodically opened (within the long-term closed areas) or closed to scallop fishing; grey areas: voluntarily closed by the Canadian scallop industry $(\mathrm{C} 1-\mathrm{C} 3, \mathrm{~A} / \mathrm{B})$ 


\section{MATERIALS AND METHODS}

Observations of scallops from 2014 to 2016 in 2 adjacent areas on Browns Bank, Canada, were made using a drop camera with a centric systematic sampling design (Carey \& Stokesbury 2011, Stokesbury et al. 2016, Bethoney \& Stokesbury 2018). Survey stations were positioned on $1 \times 1 \mathrm{~km}$ grids, with the extent of the survey stations approximately matching the borders of 2 areas ( $\mathrm{C} 2$ and $\mathrm{C} 3$ ) voluntarily closed to scallop fishing (Fig. 2, J. Mosher pers. comm.). At each station, a sampling pyramid was lowered to the sea floor 4 times. Mounted on the pyramid were 2 downward-facing video cameras, which provided quadrat samples of 0.60 and $2.84 \mathrm{~m}^{2}$, respectively, and a digital still camera that provided $1.70 \mathrm{~m}^{2}$ quadrat samples (Fig. 3). The time, depth, number of live and dead scallops, latitude, and longitude were recorded at each station. After each survey, video recordings were reviewed in the laboratory and a still image of each quadrat was captured. Within each quadrat, macroinvertebrates and fish were counted and the substrate was identified. When possible, fish and macroinvertebrates were identified to species, otherwise animals were grouped into categories based on taxonomic orders (Stokesbury \& Harris 2006). Sediments were visually identified using texture, color, relief, and structure in the video and still images, roughly following the Wentworth particle grade scale where sand $=0.0625$ to $2.0 \mathrm{~mm}$, gravel $=2.0$ to $256.0 \mathrm{~mm}$ and boulders $>256.0 \mathrm{~mm}$. Gravel was divided into 2 categories: granule-pebble $=2.0$ to $64.0 \mathrm{~mm}$ and cobble $=64.0$ to $256.0 \mathrm{~mm}$ (Wentworth 1922). Stations were categorized by the presence of the largest type of particle observed in a quadrat (Harris \& Stokesbury 2010). The shell height (distance from the umbo to the front of the shell, in $\mathrm{mm}$ ) of each scallop with a complete visible length was measured using Image Pro Plus ${ }^{\circledR}$ software. Scallops measured in the largest quadrat size were used for all analyses as this camera was the only one deployed in all $3 \mathrm{yr}$, but images from the other cameras were used to aid in scallop identification. To focus analysis on tracking scallops observed in 2014, only scallops $>40 \mathrm{~mm}$ in 2015 and $>50 \mathrm{~mm}$ in 2016 were included; scallops smaller than this would not have been picked up in our 2014 survey because the image resolution was too low (Marino et al. 2007).

Mean densities and standard errors of scallops, sea stars Asterias spp., and decapod scallop predators (Cancer irroratus, C. borealis, Homarus americanus) for each area and year were calculated using equations for a 2-stage sampling design (Cochran 1977). The mean of the total sample was calculated as:

$$
\overline{\bar{X}}=\sum_{i=1}^{\mathrm{n}}\left(\frac{\bar{x}_{1}}{\mathrm{n}}\right)
$$

where $\mathrm{n}$ is the number of stations and $\bar{x}_{i}=$ is the mean animal count from the 4 quadrats sampled at station $i$. The standard error of this mean is:

$$
\mathrm{SE}(\bar{X})=\sqrt{\frac{1}{\mathrm{n}}\left(s^{2}\right)}
$$

where $s^{2}=\sum\left(\bar{x}_{i}-\bar{x}\right)^{2} /(\mathrm{n}-1)$, which is the variance among primary unit (stations) means. According to Cochran (1977), this simplified version of the 2-stage variance is possible when the sampling fraction is small. This is the case for the drop camera survey, where thousands of $\mathrm{m}^{2}$ were sampled compared to millions of $\mathrm{m}^{2}$ in the study area.

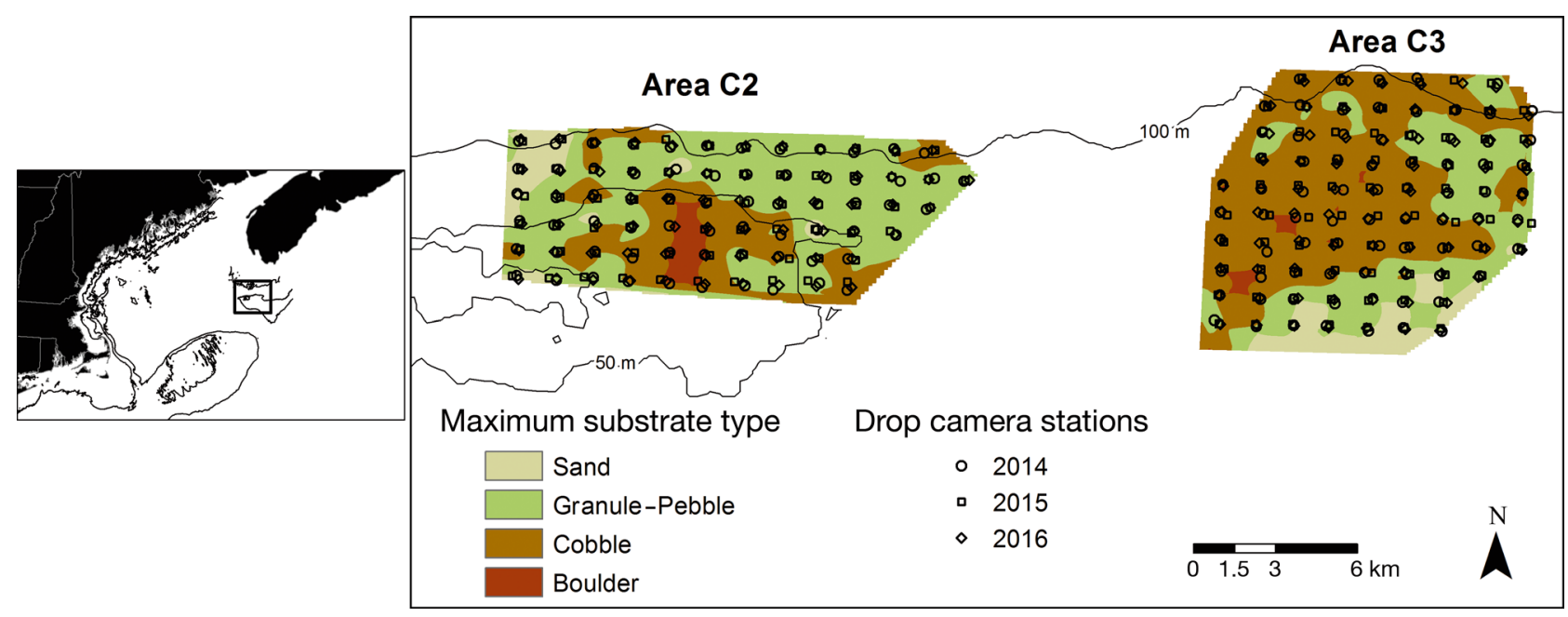

Fig. 2. Drop camera survey stations and the largest substrate type in 2 areas on Browns Bank, Canada, closed to Atlantic sea scallop fishing from 2014-2016 


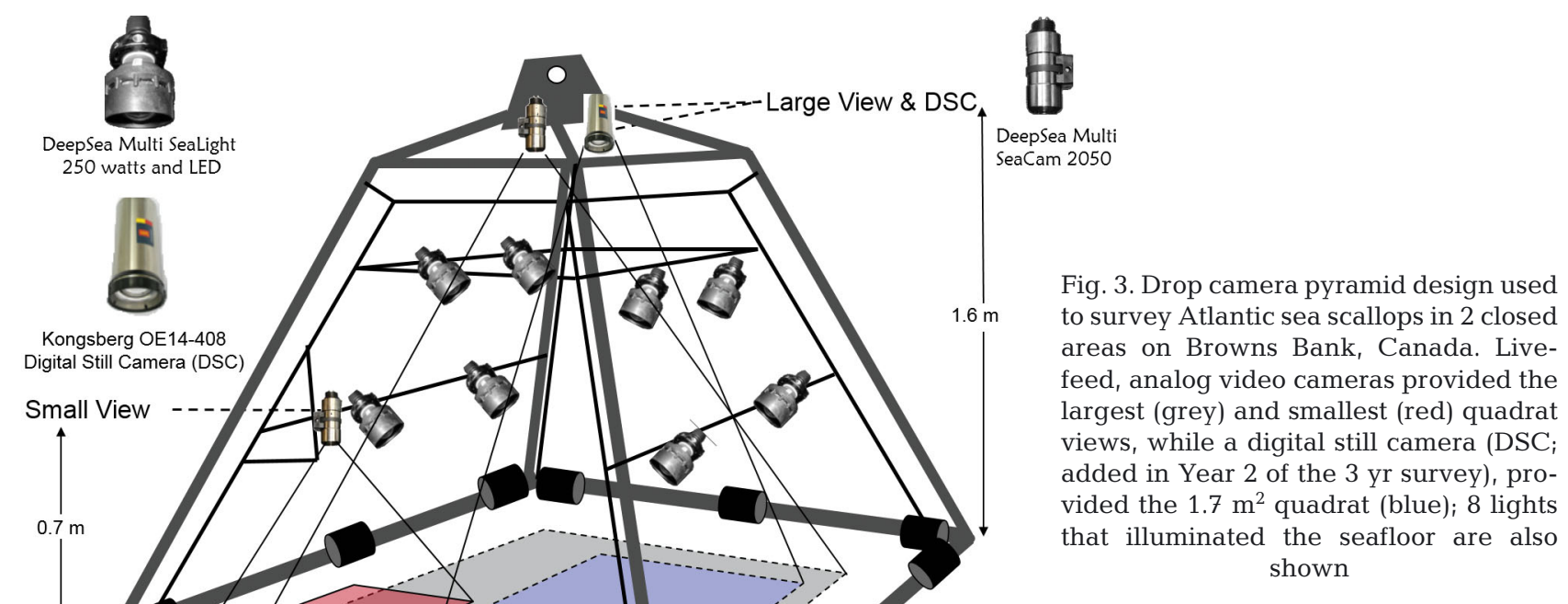

Mean crowding (which measures the average number of individuals around an individual rather than individuals per unit area) and standard errors of scallops for each area and year were calculated using equations for a quadrat sampling design (Lloyd 1967, Carey \& Stokesbury 2011):

$$
\dot{x}=\bar{x}_{1}+\frac{\bar{x}_{1}}{\hat{k}}
$$

where $\dot{x}$ is mean crowding, $\bar{x}_{l}$ is the average number of scallops per quadrat, and $\hat{k}$ is the approximate estimate of the negative binomial parameter. An approximate estimate of the negative binomial parameter was used because although more than 20 quadrats were sampled, the frequency distribution of the number of scallops per quadrat was skewed right (Krebs 1989). The standard error for $x$ is:

$$
\mathrm{SE}(\dot{x}) \approx \frac{\bar{x}_{l}}{\hat{k}^{2}} \sqrt{\operatorname{var}(\hat{k})}+\frac{\hat{k}\left(x_{l}+\hat{k}\right)(1+\hat{k})^{2}}{q \bar{x}_{l}}
$$

where $q$ is the number of quadrat samples and $\widehat{\operatorname{var}(\hat{k})}$ is the variance for the approximate estimate of the negative binomial parameter using $s^{2}$ (Bliss \& Fisher 1953).

To evaluate differences in density between areas and years, 2-way ANOVAs were used, with scallop, sea star, and decapod density, and scallop crowding as dependent variables, and area and year as fixed factors. This test was more appropriate than a repeated measures approach because we did not examine the same plots of ocean floor each year. Although
Fig. 3. Drop camera pyramid design used to survey Atlantic sea scallops in 2 closed areas on Browns Bank, Canada. Liveviews, while a digital still camera (DSC; added in Year 2 of the 3 yr survey), provided the $1.7 \mathrm{~m}^{2}$ quadrat (blue); 8 lights shown

the same stations were sampled each year, exact positions varied by $100 \mathrm{~s}$ of $\mathrm{m}$ between years and the location of each quadrat sample was random. Pairwise year comparisons were made using a Tukey's post hoc test if initial model results were significant. These statistical analyses were conducted on $\log (x+1)$ transformations of count data, so that the assumptions of the tests were not violated by rightskewed data (Zar 1996a). To further examine differences in scallops per quadrat, frequency distributions were compared within an area and between C2 and C3 annually using Kolmogorov-Smirnov tests with the test statistic critical level adjusted to the number of independent samples (survey stations with measurements) taken for each comparison (Siegel \& Castellan 1988). Changes in shell height distributions of scallops in each area and year were compared in the same manner as scallop per quadrat distributions. The largest substrate type observed at each station was pooled over the $3 \mathrm{yr}$ and a chi-squared test was used to test for heterogeneity in distributions between areas (Zar 1996b). These values were also mapped in ArcGIS v.10.5 (ESRI) using Sibson's natural neighbor method (Sibson 1981, Harris \& Stokesbury 2010). The average depths of stations in C2 and C3 were also compared using a $t$-test. All statistical tests were conducted in SPSS v.24 (IBM) or Excel 2016 (Microsoft).

\section{RESULTS}

Scallop density and crowding significantly changed over time, but decapod density did not (Tables 1 \& 2). The change in scallop density and crowding was due 
Table 1. Drop camera survey data for 2 areas on Browns Bank (C2 and C3) using estimates derived from large quadrat $\left(2.84 \mathrm{~m}^{2}\right)$ observations. A total of 4 quadrats were observed at each station. Standard errors are reported in parenthesis next to all estimates of means

\begin{tabular}{|lccccccc|}
\hline Year & Stations & Scallops $\mathrm{m}^{-2}$ & Sea stars ${ }^{-2}$ & Decapods ${ }^{-2}$ & $\begin{array}{c}\text { Crowding } \\
\text { (scallops per scallop) }\end{array}$ & $\begin{array}{c}\text { No. of scallops } \\
\text { measured }\end{array}$ & $\begin{array}{c}\text { Shell height } \\
(\mathrm{mm})\end{array}$ \\
\hline Area C2 & & & & & & & \\
2014 & 68 & $4.64(1.00)$ & $0.51(0.10)$ & $0.02(0.01)$ & $56.0(9.92)$ & 3587 & $69.5(0.34)$ \\
2015 & 67 & $6.00(1.32)$ & $0.24(0.04)$ & $0.05(0.01)$ & $72.9(13.00)$ & 4633 & $85.1(0.20)$ \\
2016 & 68 & $2.59(0.56)$ & $0.09(0.03)$ & $0.03(0.01)$ & $32.0(5.85)$ & & 1965 \\
Area C3 & 78 & $4.21(0.62)$ & $0.43(0.04)$ & $0.03(0.01)$ & $33.9(4.07)$ & 3781 & $65.7(0.36)$ \\
2014 & 79 & $3.03(0.44)$ & $0.14(0.05)$ & $0.02(0.01)$ & $23.3(2.72)$ & 2726 & $81.2(0.41)$ \\
2015 & 78 & $2.29(0.37)$ & $0.13(0.02)$ & $0.02(<0.01)$ & $19.7(2.60)$ & 2037 & $93.0(0.40)$ \\
2016 & & & & & & & \\
\hline
\end{tabular}

to significantly lower values in 2016 compared to 2014 (Tukey's post hoc test $\mathrm{p}<0.04$; Table 1). Scallop densities between areas were similar but mean crowding differed significantly (Tables 1 \& 2). Sea star density was higher in 2014 compared to 2015 and 2016, but did not differ between areas (Tables 1 \& 2). A significant interaction between year and area occurred for sea star density (Table 2). Decapod density did not differ significantly between the areas or years (Tables $1 \& 2$ ).

The distribution of scallops per quadrat was only significantly different between C2 and C3 in 2014 $\left(D_{74,86}=0.24, \mathrm{p}<0.03 ;\right.$ Fig. 4$)$. The proportion of

Table 2. Results from 2-way ANOVAs testing the effects of year and area on Atlantic sea scallop, sea star, and decapod density, and scallop crowding for 2 areas closed to fishing on Browns Bank, Canada surveyed from 2014 to 2016. F-values are shown along with significance levels $\left({ }^{*} \mathrm{p}<0.05 ;{ }^{* *} \mathrm{p}<\right.$ $0.01 ;{ }^{* * *} \mathrm{p}<0.001$ ) and Tukey's post hoc test results for which years were significantly different. Degrees of freedom are 2 for year and 1 for area

\begin{tabular}{|lccc|}
\hline Response variable & MS & $F$-value & Differences \\
\hline Scallop density & & & \\
Year & 1.4 & $4.2^{*}$ & $2016<2014,2015$ \\
Area & 0.3 & 1.1 & \\
Year $\times$ area & 0.7 & 2.1 & \\
Scallop crowding & & & \\
Year & 2.0 & $10.9^{* * *}$ & $2016<2014,2015$ \\
Area & 2.1 & $11.3^{* * *}$ & \\
Year $\times$ area & 0.3 & 1.6 & \\
Sea star density & & & \\
Year & 1.2 & $43.9^{* * *}$ & $2014>2015,2016$ \\
Area & 0.1 & 0.3 & \\
Year $\times$ area & 0.1 & $5.0^{* *}$ & \\
Decapod density & & & \\
Year & $<0.1$ & 2.3 & \\
Area & $<0.1$ & 1.0 & \\
Year $\times$ area & $<0.1$ & 2.5 & \\
\hline
\end{tabular}

quadrats with zero scallops in area C2 during 2014 was much higher, but the quadrats with scallops had very high counts; the top $10 \%$ of scallops per quadrat in area $\mathrm{C} 2$ ranged from 48 to 133 compared to 35 to 95 in area C3. In 2016, the largest difference between the 2 areas was still the number of quadrats with no scallops, but the cumulative difference was smaller as the range of the area $\mathrm{C} 2$ distribution contracted (Fig. 4). The distribution of scallop shell heights was significantly different within C2 in 2014 compared to 2015 and 2016 (Table 3, Fig. 5). No change in shell height distribution between 2015 and 2016 was found (Table 3, Fig. 5). In C3 the distribution of scallop shell heights changed significantly each year (Table 3, Fig. 5) Scallop shell height distributions between areas during the same year were similar (Table 3, Fig. 5).

Substrate type was significantly different between the 2 areas, with $\mathrm{C} 2$ dominated by granule-pebble and C3 dominated by cobble $\left(\chi^{2}=109.5, \mathrm{df}=3, \mathrm{p}<\right.$ 0.01 ; Figs. $2 \& 6)$. The average ( $\pm 1 \mathrm{SE})$ station depth in C2 (64.2 $\pm 1.7 \mathrm{~m})$ was significantly shallower than in $\mathrm{C} 3(79.9 \pm 0.9 \mathrm{~m}$; $t$-test with unequal variances, $\left.t_{307}=-8.31, \mathrm{p}<0.01\right)$.

\section{DISCUSSION}

Scallop growth differed between 2 adjacent areas with similar densities but distinct levels of crowding. Density and crowding decreased through time, primarily due to natural mortality, but crowding levels may have also been influenced by dispersal. Though most dispersal occurs when scallops first settle, scallops can still effectively swim at the mean sizes observed (Brand 2016). Crowding levels were so high in comparison to previous observations that small-scale dispersal may have continued for longer 


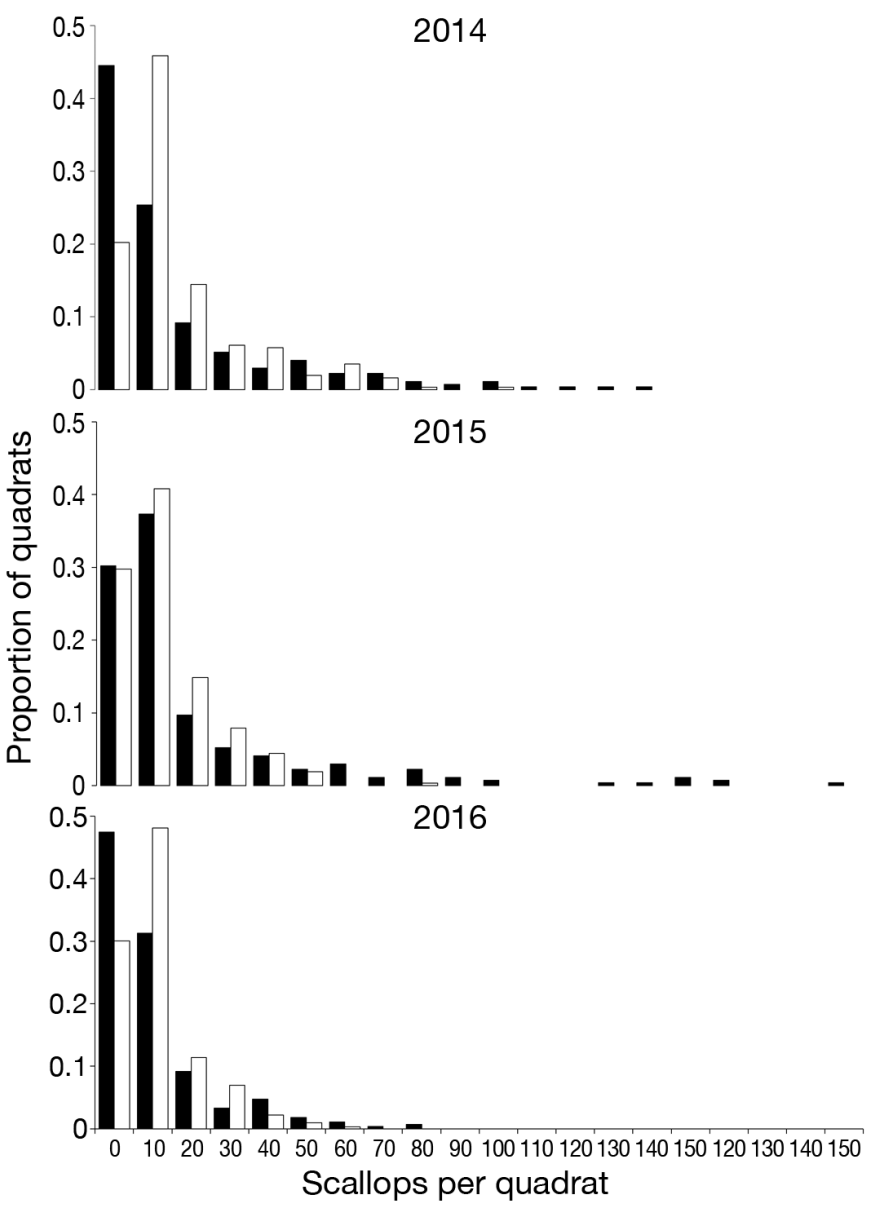

Fig. 4. Number of Atlantic sea scallops observed in $2.84 \mathrm{~m}^{2}$ quadrats in 2 areas closed to fishing on Browns Bank (C2 black, C3 white) from 2014-2016. Scallops quadrat ${ }^{-1}$ are shown in 10 count bins (i.e. $10=1-10$ scallops in a quadrat)

than usual (Carey \& Stokesbury 2011, Harris et al. 2018). Dispersal on this scale would be unlikely to influence density estimates, which were dominated by stations without scallops, but could be detected by crowding, which is only influenced by quadrats with scallops and reflects the number of other scallops around an individual scallop.

Table 3. Results from Kolmogorov-Smirnov tests comparing shell height distributions of Atlantic sea scallops between years within an area and between areas in the same area. Bold indicates significance at $\alpha \leq 0.05$

\begin{tabular}{|c|c|c|c|c|c|c|}
\hline \multirow{2}{*}{ Year } & \multirow{2}{*}{ Area } & \multirow{2}{*}{$\begin{array}{c}2014 \\
\text { C3 }\end{array}$} & \multicolumn{2}{|c|}{2015} & \multicolumn{2}{|c|}{$2016-$} \\
\hline & & & C2 & C3 & $\mathrm{C} 2$ & C3 \\
\hline 2014 & $\mathrm{C} 2$ & $D_{51,75}=0.15$ & $D_{51,62}=0.33$ & & $D_{51,45}=0.36$ & \\
\hline & C3 & & & $D_{75,72}=0.33$ & & $D_{75,66}=0.51$ \\
\hline 2015 & $\mathrm{C} 2$ & & & $D_{62,72}=0.10$ & $D_{62,45}=0.04$ & \\
\hline & C3 & & & & & $D_{72,66}=0.24$ \\
\hline 2016 & $\mathrm{C} 2$ & & & & & $D_{45,66}=0.15$ \\
\hline
\end{tabular}

Despite showing a similar declining trend in population size, density and crowding diverged in their characterization of the intensity of scallop aggregations in the 2 areas. The conflicting results indicate that scallops in area $\mathrm{C} 2$ were less dispersed, resulting in more zero observations and more extremely high observations than in area C3. Scallop patchiness almost always results in zero-dominated data sets when observing distributions on the scale of $\mathrm{km}$ (Orensanz et al. 2016, Harris et al. 2018). Thus, mean density accurately estimates abundance if enough samples are collected but does not reflect the patchiness of scallops (this is represented in the variance). In contrast, crowding levels were influenced only by quadrats with scallops and showed a distinct difference between the intensity of aggregations in the areas (Table 1). This was also evident in the distributions of the number of scallops per quadrat, which were initially different between the 2 areas due to a higher proportion of quadrats with zero or very high numbers of scallops in C2 (Fig. 4).

Though both areas were in close proximity, finescale differences in predator levels and settlement dynamics may have caused different initial crowding levels (Orensanz et al. 2016). Predator levels in the 2 areas were similar, refuting the notion that higher predation levels reduced crowding. The higher sea star densities seen in 2014 were likely influenced by higher scallop density and crowding levels that would provide a higher encounter rate for predation and scavenging (Nadeau et al. 2009). This may also explain the interaction between area and year on sea star density, as area C2 had higher crowding levels than area C3 and appeared to have higher sea star densities as well until scallop crowding in the area significantly declined in 2016 (Table 1). However, scallops in these areas likely settled between 2012 and 2013, leaving the possibility of a discrepancy between predator densities at the time of settlement and this study. For example, predators may have dissipated by 2014 due to increases in scallop size.

A clear difference between the 2 areas was the dominance of granule-pebble substrate in area $\mathrm{C} 2$ compared to cobble in area C3 (Fig. 6). Granule-pebble is optimal for post-larval settlement, indicating a higher ceiling for crowding in area C2. However, the primary benefits of granule-pebble substrate for post-larval settlement, predator protection and stable substrate, can also be provided by 


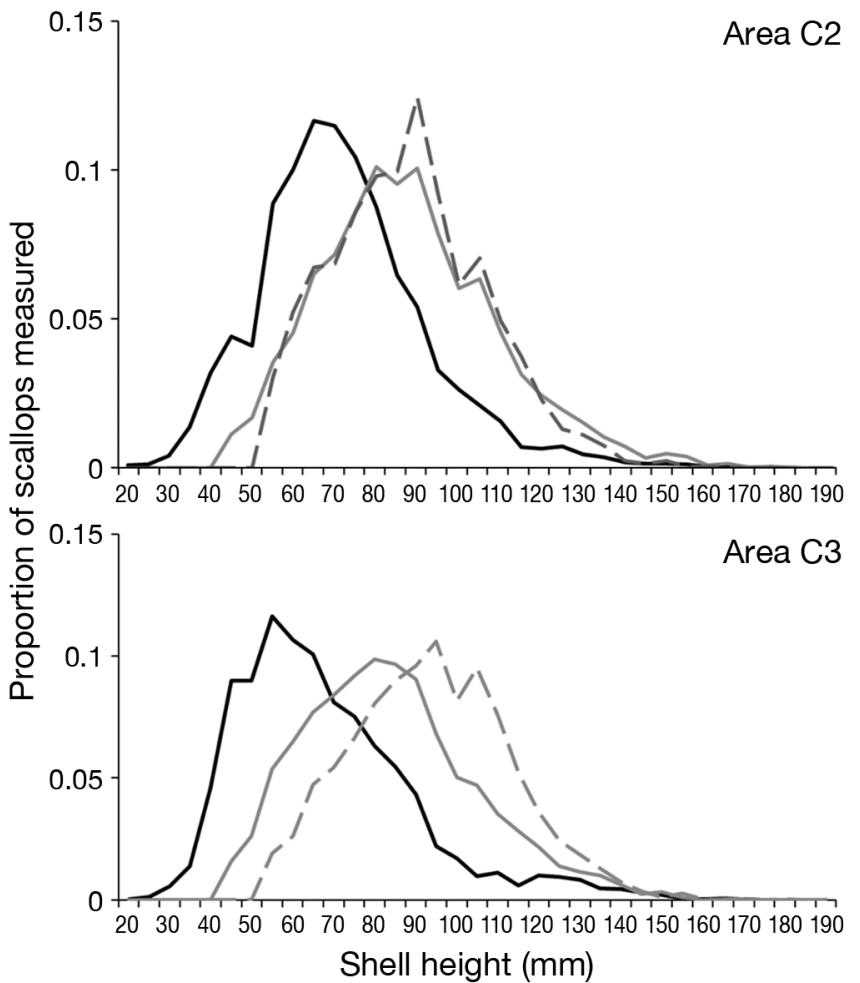

Fig. 5. Shell height distribution of Atlantic sea scallops in 2 areas on Browns Bank (C2 and C3) during a 3 yr fishery closure (black: 2014; grey: 2015; dashed: 2016). To focus on tracking scallops observed in 2014, only scallops $>40 \mathrm{~mm}$ in 2015 and $>50 \mathrm{~mm}$ in 2016 were included in shell height distributions

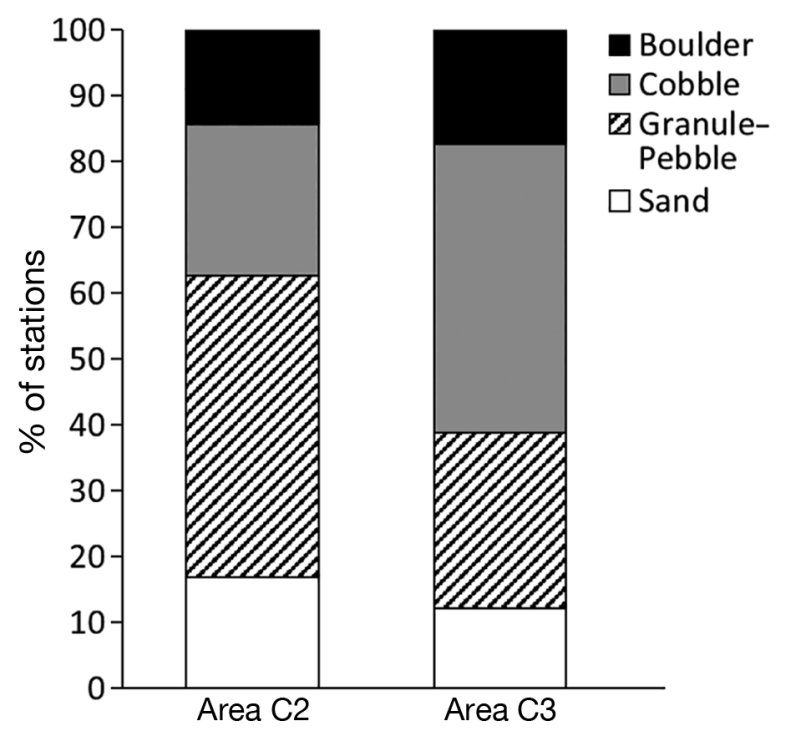

Fig. 6. Sediment composition, defined by largest substrate type at a drop camera station, in 2 areas on Browns Bank (C2 and C3) during a 3 yr Atlantic sea scallop fishery closure. Vertical axis: percent of stations cobble substrate (Thouzeau et al. 1991, Stokesbury \& Himmelman 1995). Unlike scallops settling on top of gravel, scallops on top of cobble substrate would become unstable once they grew larger than the piece of cobble and would not be able to form depressions that enhance feeding (Yager et al. 1993). Scallops would have to settle between pieces of cobble to avoid these negative aspects. Thus, cobble takes up space where scallops could have settled, reducing the settlement space available and forcing scallops to spread out and reduce crowding levels.

The 2 areas exhibited different growth patterns over time, resulting in different levels of closure effectiveness. The change in the shell height frequency distribution in area $\mathrm{C} 3$ each year showed a continued increase in the overall size of scallops through the 3 yr closure (Fig. 5). In contrast, the same metric in area $\mathrm{C} 2$ showed no overall change in size between 2015 and 2016 (Fig. 5). The growth equation used to assess scallops on Browns Bank indicates that 5 to $6 \mathrm{yr}$ old scallops would be approximately 90 to $100 \mathrm{~mm}$ in shell height (Hubley et al. 2014). This suggests the lack of size increase from 2015 to 2016 in area $\mathrm{C} 2$ resulted in more scallops undersized for their age. Combining these results with the decreases in scallop density suggests yield was lost between Years 2 and 3 in the area C2 closure, while the 3 yr closure in area C3 achieved the desired goal of increasing yield through time. Applying a standard shell-height to meat-weight ratio to shell height frequencies and comparing biomass in areas $\mathrm{C} 2$ and $\mathrm{C} 3$ in 2015 and 2016 shows exploitable biomass in area C2 declined by about $40 \%$ between 2015 and 2016, while it increased in area C3 by about $17 \%$ (Hennen \& Hart 2012).

The different levels of crowding between the 2 areas may explain the different growth patterns. Discrepancies in scallop growth can be related to several factors including depth, temperature, disease, and food availability, which can differ over small spatial scales (MacDonald et al. 2016). For example, the difference in depth between the 2 areas may expose scallops within them to different water velocity patterns and subsequently to different water temperatures, salinity, and levels of food (Hannah et al. 2001). Such small-scale complexity may explain the lack of correlation of scallop condition to temperature and depth over the whole of Browns Bank (Hubley et al. 2014). The impact these environmental factors have on growth can be influenced by high local density (crowding). At high densities, food depletion is the primary factor for decreases in shell growth (MacDonald \& Thompson 1985, Côté et al. 1994) and 
as scallops grow and mature, they require more food (MacDonald et al. 2016). Thus, food levels initially may have been adequate to support similar growth in both areas despite different levels of crowding, but as the scallops grew, greater competition for food in the more crowded area $\mathrm{C} 2$ may have resulted in slowed growth.

This study highlights a paradigm of spatial management that may become increasingly prevalent. The focus of temporary spatial closures in the Atlantic scallop fisheries is to prevent areas from being fished too soon (NEFMC 2004, Stevens et al. 2008). However, foregone yield due to stunted growth and continued mortality can make the timing of opening areas as important as the timing of closing them. This has been exemplified in the past, at lower scallop abundances (Stokesbury et al. 2007); but in areas of extremely high abundance, density-dependent processes add a factor that can change the effectiveness of rotational management. This study found varying effectiveness of a closure to increase yield between 2 areas that were expected to perform similarly. The major difference between the 2 areas was the level of crowding. Our study examined only 2 areas and therefore could not completely separate the effect of crowding from other possible causal site-specific differences, but it does suggest that overcrowding may have affected growth. However, decreases in scallop size and yield at age have been observed in the Nantucket Lightship and Elephant Trunk scallop rotational areas (Fig. 1), which have extremely high densities of scallops similar to C2 and C3 (NEFMC 2017, NEFSC 2018). Examining crowding levels in addition to density in other areas would allow the results to potentially be applied more generally and help move analysis from examining abundances and distribution of aggregations to the level of individuals, which is needed to examine densitydependent processes (Orensanz et al. 2016). Crowding cannot be calculated by traditional survey methods such as dredging and towing nets because these mask the distribution of individuals within the tow track. These methods do provide valuable information, such as changes in meat weight, which optical surveys cannot, emphasizing the benefit of combined approaches to monitoring (NEFSC 2018). As marine protected areas increase in prevalence, viewing limited access into areas of high biomass as 'windows of opportunity' rather than 'money in the bank' and considering divergences from typical patterns at lower biomasses will help management.
Acknowledgements. Thanks to the crew and scientists aboard the F/Vs 'Tenacity' and 'Fund Leader' who sailed on these research trips. Thanks to the students and staff that quantified the data within the images collected. Thanks to B. Rothchild, G. Robert, J. Mosher for helpful conversations and to the anonymous journal reviewers whose comments greatly improved the manuscript. Funding was provided by Clearwater Seafoods. The views expressed herein are those of the authors and do not necessarily reflect the views of Clearwater Seafoods.

\section{LITERATURE CITED}

Bethoney ND, Stokesbury KDE (2018) Methods for imagebased surveys of benthic macroinvertebrates and their habitat exemplified by the drop camera survey of the Atlantic sea scallop. J Vis Exp 137:e57493

Bethoney ND, Asci S, Stokesbury KDE (2016) Implications of extremely high recruitment events into the US sea scallop fishery. Mar Ecol Prog Ser 547:137-147

Beverton RJH, Holt SJ (1957) On the dynamics of exploited fish populations. Her Majesty's Stationary Office; facsimile reprint by Chapman \& Hall, London, 1993

Bliss CI, Fisher RA (1953) Fitting the negative binomial distribution to biological data. Biometrics 9:176-200

Boonzaier L, Pauly P (2016) Marine protection targets: an updated assessment of global progress. Oryx 50:27-35

Brand AR (2016) Scallop ecology: distribution and behavior. In: Shumway S, Parsons GJ (eds) Scallops: biology, ecology, aquaculture, and fisheries, 3rd edn. Elsevier, Amsterdam, p 469-535

Carey JD, Stokesbury KDE (2011) An assessment of juvenile and adult sea scallop, Placopecten magellanicus, distribution in the northwest Atlantic using high-resolution still imagery. J Shellfish Res 30:569-582

Cochran WG (1977) Sampling techniques, 3rd edn. John Wiley \& Sons, New York, NY

* Côté J, Himmelman JH, Claereboudt MR (1994) Separating effects of limited food and space on growth of the giant scallop Placopecten magellanicus in suspended culture. Mar Ecol Prog Ser 106:85-91

DFO (Department of Fisheries and Oceans Canada) (2015) Seafisheries 2015 value of Atlantic landings. www.dfompo.gc.ca/stats/commercial/land-debarq/sea-maritimes/ s2015av-eng.htm (accessed February 2018)

DFO (2017) Stock status update of Georges Bank scallops (Placopecten magellanicus). DFO Canadian Science Advisory Secretariat Science Response 2017/033

*Guidetti P, Claudet J (2010) Comanagement practices enhance fisheries in marine protected areas. Conserv Biol 24:312-318

* Hannah CG, Shore JA, Loder J, Naimie CE (2001) Seasonal circulation on the western and central Scotian Shelf. J Phys Oceanogr 31:591-615

* Harris BP, Stokesbury KDE (2010) The spatial structure of local surficial sediment characteristics on Georges Bank, USA. Cont Shelf Res 30:1840-1853

* Harris BP, Adams CF, Stokesbury KDE (2018) Sea scallops exhibit strong local spatiotemporal structure associated with seabed stability and high flows. Ecosphere 9: e02133

*Hart DR, Chute AS (2009) Estimating von Bertalanffy growth parameters from growth increment data using a linear mixed-effects model, with an application to the sea 
scallop Placopecten magellanicus. ICES J Mar Sci 66: 2165-2175

Hennen DR, Hart DR (2012) Shell height-to-weight relationships for Atlantic sea scallops (Placopecten magellanicus) in offshore US waters. J Shellfish Res 31:1133-1144

Hubley PB, Reeves A, Smith SJ, Nasmith L (2014) Georges Bank 'a' and Browns Bank 'North' scallop (Placopecten magellanicus) stock assessment. DFO Canadian Science Advisory Secretariat Research Document 2013/079

Krebs CJ (1989) Estimating abundance: quadrat counts and line transects. In: Ecological methodology. HarperCollins Publishers, New York, NY, p 64-121

Lloyd M (1967) Mean crowding. J Anim Ecol 36:1-30

MacDonald BA, Thompson RJ (1985) Influence of temperature and food availability on the ecological energetics of the giant scallop Placopecten magellanicus. I. Growth rates of shell and somatic tissue. Mar Ecol Prog Ser 25: 279-294

MacDonald BA, Bricelj VM, Shumway SE (2016) Physiology: energy acquisition and utilization. In: Shumway S, Parsons GJ (eds) Scallops: biology, ecology, aquaculture, and fisheries $3^{\text {rd }}$ edn. Elsevier, Amsterdam, p 301-355

Marino MC II, O'Keefe CE, Jacobson LD (2007) Selectivity and efficiency of large camera video data from the SMAST video survey during 2003-2006. Appendix B7 to NEFSC SAW 45. Northeast Fisheries Science Center, Woods Hole, MA

McDermott S, Buhl-Mortensen L, Dahle G, Hart DR, Haynie AC and others (2017) Lessons on marine protected area management in northern boreal regions from the United States and Norway. Mar Fish Rev 79:28-51

Murawski SA, Brown R, Lai HL, Rago PJ, Hendrickson L (2000) Large-scale closed areas as a fishery-management tool in temperate marine ecosystems: the Georges Bank experience. Bull Mar Sci 66:775-798

Nadeau M, Barbeau MA, Brêthes J (2009) Behavioral mechanisms of sea stars (Asterias vulgaris Verrill and Leptasteria polaris Müller) and crabs (Cancer irroratus Say and Hyas araneus Linnaeus) preying on juvenile sea scallops (Placopecten magellanicus (Gemelin)), and procedural effects of scallop tethering. J Exp Mar Biol Ecol 374: 134-143

NEFMC (New England Fishery Management Council) (2004) Final amendment 10 to the Atlantic Sea Scallop Fishery Management Plan with a supplemental environmental impact statement, regulatory impact review and regulatory flexibility analysis. NEFMC, Newburyport, MA

NEFMC (2017) Scallop plan development team recommendations for OFL and ABC for Framework 28 (FY2017 and FY2018 default). NEFMC, Newburyport, MA

NEFSC (Northeast Fisheries Science Center) (2018) Sea scallop assessment summary for 2018. In: 65th Northeast Regional Stock Assessment Workshop (65th SAW) Assessment Summary Report. NEFSC Ref Doc 18-08, Northeast Fisheries Science Center, Woods Hole, MA, p 13-19

Editorial responsibility: Jean-Sébastien Lauzon-Guay, Dartmouth, Nova Scotia, Canada
NOAA (National Oceanic and Atmospheric Administration) (2016) Annual commercial landings statistics. www.st. nmfs.noaa.gov/st1/commercial/landings/annual_landings. html (accessed February 2018)

Orensanz JM, Parma AM, Smith SJ (2016) Dynamics, assessment, and management of exploited natural scallop populations. In: Shumway S, Parsons GJ (eds) Scallops: biology, ecology, aquaculture, and fisheries, $3^{\text {rd }}$ edn. Elsevier, Amsterdam, p 611-697

Rose KA, Cowan JH, Winemiller KO, Myers RA, Hiborn R (2001) Compensatory density dependence in fish populations: importance, controversy, understanding and prognosis. Fish Fish 2:293-327

Sibson R (1981) A brief description of natural neighbor interpolation. In: Barnett $\mathrm{V}$ (ed) Interpreting multivariate data. Wiley Press, New York, NY, p 21-36

Siegel S, Castellan NJ (1988) The Kolmogorov-Smirnov twosample test. In: Anker JD (ed) Nonparametric statistics for the behavioral sciences, 2nd edn. McGraw-Hill, New York, NY, p 144-151

Stevens G, Robert J, Burke L, Pouillioux D, Roussel D, Wilson J (2008) The evolution of management in Canada's offshore scallop fishery. In: Townsend R, Shotton R, Uchida H (eds) Case studies in fisheries self governance. Tech Pap No. 504, Food and Agriculture Organization of the United Nations, Rome, p 111-123

Stokesbury KDE, Harris BP (2006) Impact of limited shortterm sea scallop fishery on epibenthic community of Georges Bank closed areas. Mar Ecol Prog Ser 307: 85-100

Stokesbury KDE, Himmelman JH (1995) Examination of orientation of the giant scallop, Placopecten magellanicus, in natural habitats. Can J Zool 73:1945-1950

* Stokesbury KDE, Harris BP, Marino MC II, Nogueira JI (2007) Sea scallop mass mortality in a Marine Protected Area. Mar Ecol Prog Ser 349:151-158

Stokesbury KDE, O'Keefe CE, Harris BP (2016) Fisheries sea scallop, Placopecten magellanicus. In: Shumway S, Parsons GJ (eds) Scallops: biology, ecology, aquaculture, and fisheries, 3rd edn. Elsevier, Amsterdam, p 719-737

Thouzeau G, Robert G, Smith SJ (1991) Spatial variability in distribution and growth of juvenile and adult sea scallops Placopecten magellanicus (Gmelin) on eastern Georges Bank (Northwest Atlantic). Mar Ecol Prog Ser 74: 205-218

Wentworth CK (1922) A grade scale and class terms for clastic sediments. J Geol 30:377-392

Yager PL, Nowell ARM, Jumars PA (1993) Enhanced deposition to pits: a local food source for benthos. J Mar Res 51:209-236

Zar J (1996a) Data transformations. In: Snavely SL (ed) Biostatical analysis, 3rd edn. Prentice-Hall, Upper Saddle River, NJ, p 277-285

Zar J (1996b) Testing for goodness of fit. In: Snavely SL (ed) Biostatical analysis, 3rd edn. Prentice-Hall, Upper Saddle River, NJ, p 457-483

Submitted: April 16, 2018; Accepted: January 16, 2019

Proofs received from author(s): February 7, 2019 